\title{
Article \\ Evaluation of the Effectiveness of Spirotetramat on the
Diaspine Scale Parlatoria pergandii in Citrus Orchards
}

\author{
Amine Assouguem ${ }^{1}{ }^{(}$, , Mohammed Kara $\left.{ }^{2}{ }^{(}\right)$, Ismail Mansouri ${ }^{1}$, Hamada Imtara ${ }^{3} \mathbb{D}$, Mashail N. AlZain ${ }^{4}$, \\ Hamza Mechchate ${ }^{5, *} *$ , Raffaele Conte ${ }^{6}{ }^{(0)}$, Wafae Squalli ${ }^{1}$, Abdellah Farah ${ }^{7}$ and Abderrahim Lazraq ${ }^{1}$
}

1 Laboratory of Functional Ecology and Environment, Faculty of Sciences and Technology, Sidi Mohamed Ben Abdellah University, Imouzzer Street, Fez P.O. Box 2202, Morocco; assougam@gmail.com (A.A.); mankhori@gmail.com (I.M.); wafaesqualli7@gmail.com (W.S.); lazraqab@gmail.com (A.L.)

2 Laboratory of Biotechnology and Conservation and Valorization of Natural Resources (LBCVRN) (ex LBPRN), Sidi Mohamed Ben Abdellah University, Fez B.P. 1796, Morocco; mohammed.kara@usmba.ac.ma

3 Faculty of Arts and Sciences, Arab American University Palestine, Jenin P.O. Box 240, Palestine; hamada.tarayrah@gmail.com

4 Department of Biology, College of Sciences, Princess Nourah Bint Abdulrahman University, Riyadh 11451, Saudi Arabia; mnalzain@pnu.edu.sa

5 Laboratory of of Biotechnology, Environment, Agri-Food, and Health (LBEAS), Faculty of Science Dhar El Mahraz, Sidi Mohamed Ben Abdellah University, Fez B.P. 1796, Morocco

6 Research Institute on Terrestrial Ecosystems (IRET) —CNR, Via Pietro Castellino 111, 80131 Naples, Italy; Raffaele.conte86@tiscali.it

check for updates

Citation: Assouguem, A.; Kara, M.; Mansouri, I.; Imtara, H.; AlZain, M.N.; Mechchate, H.; Conte, R.; Squalli, W.; Farah, A.; Lazraq, A. Evaluation of the Effectiveness of Spirotetramat on the Diaspine Scale Parlatoria pergandii in Citrus Orchards. Agronomy 2021, 11, 1562. https:// doi.org/10.3390/agronomy11081562

Academic Editor: Álvaro Rodríguez González

Received: 19 June 2021

Accepted: 4 August 2021

Published: 5 August 2021

Publisher's Note: MDPI stays neutral with regard to jurisdictional claims in published maps and institutional affiliations.

Copyright: (c) 2021 by the authors. Licensee MDPI, Basel, Switzerland. This article is an open access article distributed under the terms and conditions of the Creative Commons Attribution (CC BY) license (https:// creativecommons.org/licenses/by/ $4.0 /)$.
7 Laboratory of Applied Organic Chemistry, Faculty of Sciences and Technology, Sidi Mohamed Ben Abdellah University, Imouzzer Street, Fez P.O. Box 2202, Morocco; farah.abdellah1@gmail.com

* Correspondence: Hamza.mechchate@usmba.ac.ma

Abstract: The control of Parlatoria pergandii (Comstock, 1881) was studied in citrus orchards at Belksiri (Gharb area), Morocco. Three concentrations of Spirotetramat (T0 = $0 \mathrm{~L} / \mathrm{Ha}, \mathrm{T} 1=0.625 \mathrm{~L} / \mathrm{Ha}$, $\mathrm{T} 2=0.755 \mathrm{~L} / \mathrm{Ha}$, and T3 = $1 \mathrm{~L} / \mathrm{Ha}$ ) were applied to 4 ha of Valencia late orchard (each dose for 1 ha of citrus). The insecticidal of Spirotetramat was evaluated on two stages of larvae (L1 and L2) of $P$. pergandii and three stages of females, F1, F2, and F3. Similarly, the rates of parasitism by Aphytis hispanicus on the females of three different stages were monitored to evaluate the impact of Spirotetramat on this natural enemy. Results showed that Spirotetramat was more effective on larvae than females. Of the females, $26.04 \%$ were parasitized, $65.81 \%$ were inhibited, and only $8.15 \%$ were intact after the treatment period. Of the larvae, $79.73 \%$ were inhibited, and only $20.27 \%$ survived after the treatment period. Finally, our study highlights that all the tested concentrations of this product were effective on the population of P. pergandii. On the other hand, this product showed a less negative impact on the parasitized females with the low concentration $(0.625 \mathrm{~L} / \mathrm{Ha})$ compared to the high concentrations of the pesticide $(\mathrm{T} 2=0.755 \mathrm{~L} / \mathrm{Ha}$ and $\mathrm{T} 3=1 \mathrm{~L} / \mathrm{Ha}$ ), especially for the female stages F2 and F3. Moreover, the impact on the water table will be less severe with a low concentration.

Keywords: Parlatoria pergandii; parasitoid; pest control; Spirotetramat; Valencia late Morocco

\section{Introduction}

Citrus is one of the most essential fruit trees cultivated in the Mediterranean area [1,2]. In Morocco, the amount of land dedicated to citrus plantations is growing every year; the total annual production is $\sim 3$ million tons of citrus fruit. It is mainly produced in Souss, Berkane, Tadla and Haouz regions with a total surface area of 126.600 ha [3,4]. However, in addition to the complications of production and marketing, there are numerous pest species and diseases that are reducing the quantity and quality of citrus fruits $[5,6]$.

To date, there are more than 155 weed species, 90 pest species, 34 diseases species, and 16 nematodes in citrus farming zones, mainly in the Mediterranean region from Turkey in the East to Morocco in the far West Nadine [7-9]. Among this diversity of 
nuisances, the polyphagous Parlatoria pergandii (Comstock, 1881) (Hemiptera: Diaspididae) is one of the most widely-dispersed citrus pest species invading citrus worldwide and in Morocco [10,11]. Infestations caused by this insect pest can be documented by the occurrence of the scale-armor on citrus tree parts, including the leaves, stems, and fruits [12]. However, symptoms are mostly related to the severity of the infestation (density of pest on the host) and host immunity [13].

Infestations on the citrus trees, mainly on the stems and leaves, principally cause wilting and decrease the photosynthetic pigments and surfaces of the plants, leading to reductions in yields and revenues [14]. Generally, P. pergandii reduces the quantity and quality of citrus fruits produced. The latter decreases marketing opportunities, particularly in big markets, such as the European Union the USA where the exportation standards are more complex [15].

To control P. pergandii, many approaches, including chemical and eco-friendly methods, are used [16-18]. While in northern countries, sustainable methods are encouraged, pest management is profoundly dependent on chemical treatments in other southern countries [19]. In Morocco, before 2010, sustainable approaches were neglected and rudimentary [20]. However, with the newly imposed standards, mainly in terms of the use of chemical compounds, pesticides have become a problem because of the remaining residues on fruits. Moreover, the development of resistance to pesticides has negatively impacted production, harvesting, and exportation of citrus fruits [21].

The development cycle of P. pergandii, including the duration of each larval (L1 and L2), female (F1, F2, and F3), and male (pre-pupa, pupa, and adult) stage; fecundity; oviposition rate; and sex ratio are largely influenced by the host plant and temperature [22-24]. The life cycle lasts, on average, 56.28 days for lemons and only 45.33 days for squash. The fecundity is 86 larvae per female for lemons and 109 for squash [24]. On the other hand, the number of generations per year varies with climatic conditions-three generations in Morocco and Spain and three to four in Israel $[23,25]$.

Aphytis hispanicus (Mercet, 1912) (Hymenoptera: Aphelinidae) is an important parasite of P. pergandii in Morocco [22-24]. They develop exclusively as primary ectoparasitoids of diaspine scaled insects [26]. The adult female pierces the shield of the scale with the ovipositor and lays one or several eggs on the body of the scaled insect [27].

Spirotetramat is a systemic insecticide listed in Group 23 of the Insecticide Resistance Action Committee. It is a compound that belongs to the chemical class of ketoenols [28]. It is active against piercing-sucking insects, by acting as an acetyl-CoA carboxylase (ACC) inhibitor, interrupting lipid biosynthesis in the insects $[29,30]$. In this study, we used field monitoring to investigate the adequate dose of Spirotetramat to control P. pergandii without affecting natural enemies of the pest in citrus orchards. More specifically, we studied the lowest effective dose of Spirotetramat on larvae and females regarding its impact on the parasitoids of $P$. pergandii inside citrus orchards.

\section{Materials and Methods}

\subsection{Study Area}

Fieldwork was conducted in the Belksiri northeast of the Kenitra province, situated at the Gharb plain, North of Morocco (Figure 1). Geographically, the study zone was at low altitude ranging between 300 and $500 \mathrm{~m}$ above sea level. The Gharb region is the largest agricultural area $\left(600 \mathrm{~km}^{2}\right)$ in Morocco [31]. This region is well known for the production of fruits and vegetables, including citrus, cereals, and vegetables due to the appropriate climate and soil properties [32]. The Gharb zone is characterized by a Mediterranean climate; annual precipitation ranges between 480 and $600 \mathrm{~mm}$, and the average temperature is $27^{\circ} \mathrm{C}$ during summer and $13^{\circ} \mathrm{C}$ during winter. 


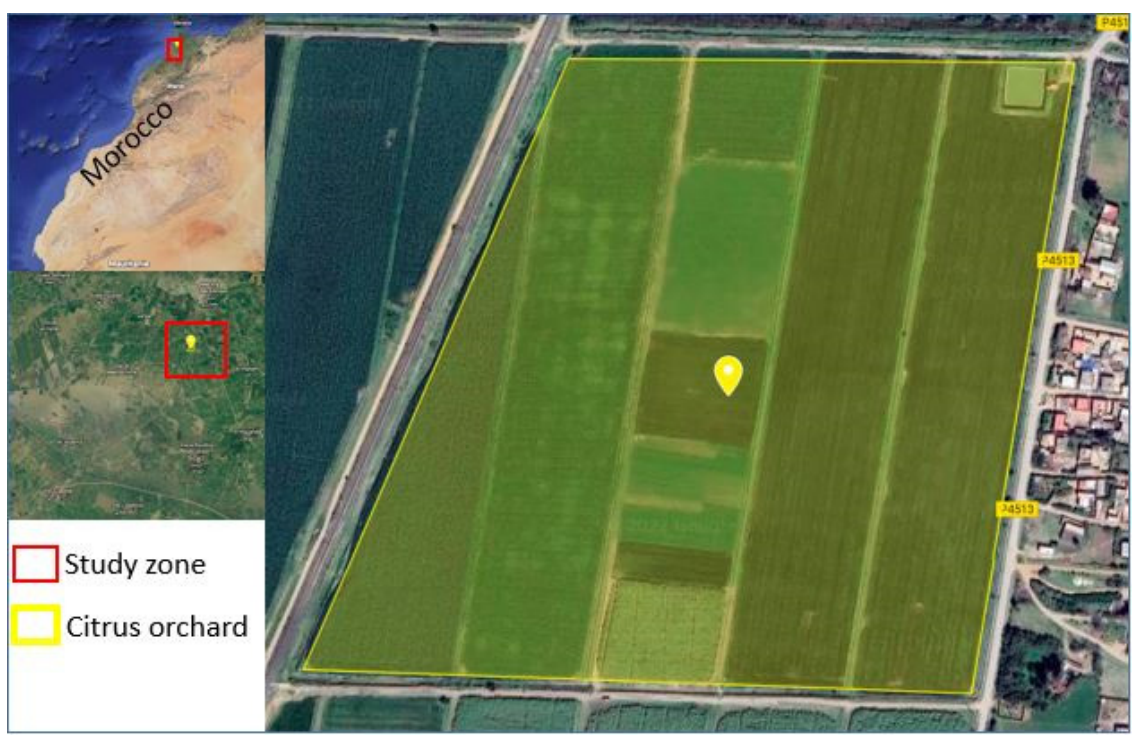

Figure 1. Location of the orchard used.

\subsection{Sampling Design}

To evaluate the effect of Spirotetramat on P. pergandii, an orchard of "Valencia Late" (Citrus sinensis) was selected and monitored because of its abundance in the area [32]. Spirotetramat was selected based on two reasons: (1) the pesticide is effective against a wide range of pests; (2) its low impacts on the environment and natural enemies. The orchard covers 4 ha with 25-year-old citrus trees. The orchard was divided into $4 \times 1$ ha small plots (Figure 2), and each plot was treated with a specific dose of the pesticide: (i) $\mathrm{T} 0=0 \mathrm{~L}$ Spirotetramat (as a control experiment), (ii) $\mathrm{T} 1=0.625 \mathrm{~L}$, (iii) $\mathrm{T} 2=0.755 \mathrm{~L}$, and (iv) T3 $=1$ L. In addition, the Teyme Eolo sprayer (Teyme Tecnologia Agricola, Girona, Spain), with its turbulent nozzle and exit diameter of $12 \mathrm{~mm}$, delivered $1.55 \mathrm{~L} / \mathrm{min}$ at a pressure of 20 bars. The towed sprayer delivers $2500 \mathrm{~L}$ of spray liquid per hectare, at a rate of $6 \mathrm{~L}$ of spray liquid for each tree, allowing us to wet all parts of the tree. (Figure 2). Concentrations were selected based mainly on the quantity of pesticide used regularly by local farmers.

To evaluate the effect of each dose, after treatment ( 1 to 8 weeks) we sampled 200 leaves from late Valencia trees in each plot. Ten leaves/tree were collected randomly from the different directions (north, east, south, and west) of the tree, for a total of 20 trees/plot that belonged to a square block (3 repetitions were performed independently). We left 2 lines between the different plots treated with this systemic product. The collected leaves were transferred directly in polyethylene bags referenced to the laboratory for examination. The scaled insect stages on each leaf were determined and counted on both surfaces of the leaves by using a binocular microscope. Then, we counted the mortalities (M) and survivals (V) of P. pergandii at two larval stages (L1 and L2) and three female stages (F1, F2, and F3). In parallel, to evaluate the effect of Spirotetramat on natural enemies of $P$. pergandii, after each treatment, we counted the parasitism rates $(\mathrm{P})$ by Aphytis hispanicus on the females at three different stages, F1, F2, and F3. Aphytis hispanicus is an important parasitoid of $P$. pergandii in the area and the Mediterranean in general. 


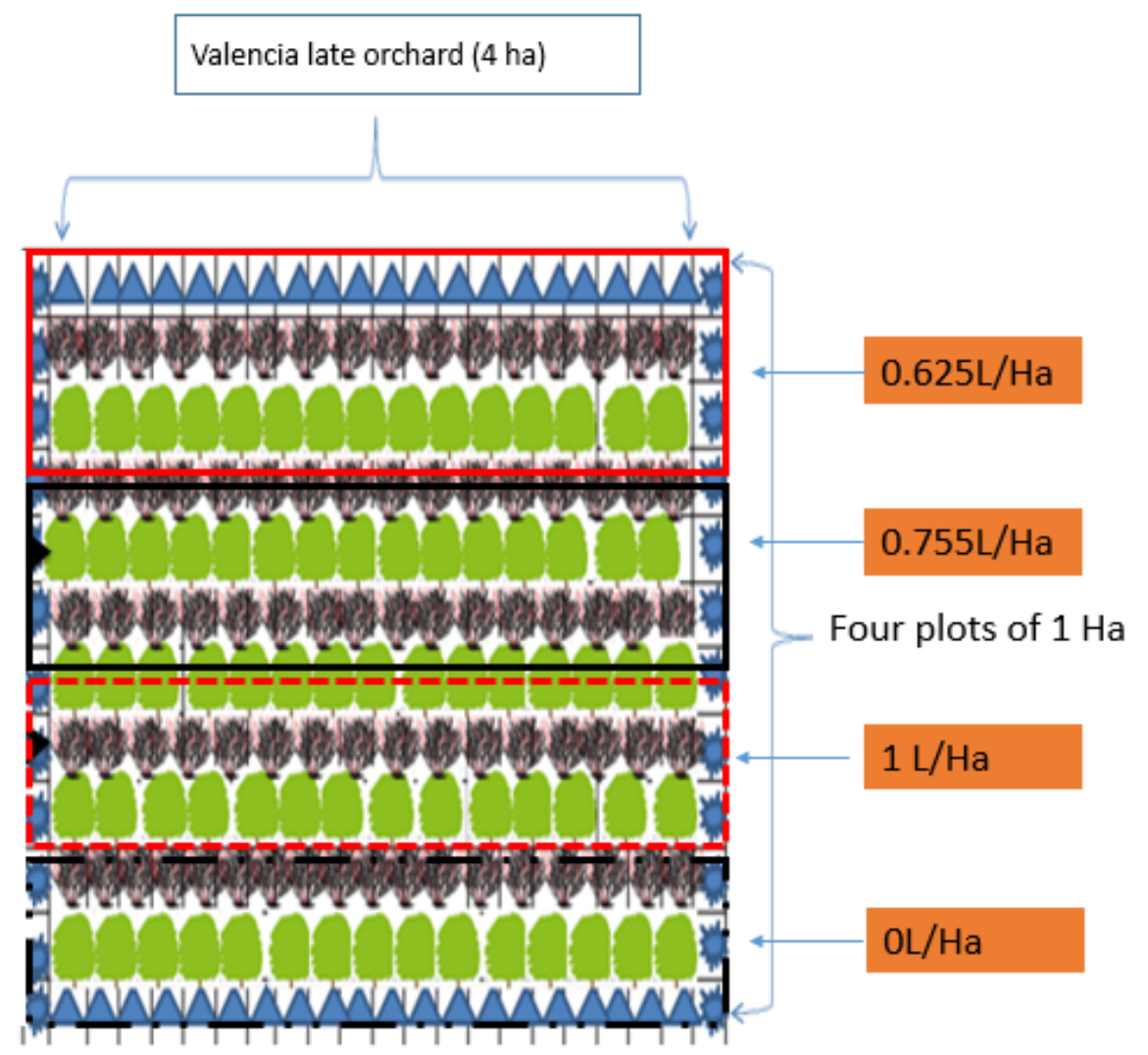

Figure 2. A model of the orchard we monitored (divided into four small plots of 1 ha) with the doses of Spirotetramat we used.

\subsection{Statistics}

Statistics were done using the Statgraphics Centurion software, version XVI.I for windows (Statgraphics Technologies, The Plains, VA, USA), and the results are given as sample size and mean \pm SD. Moreover, to evaluate the effectiveness of Spirotetramat, we calculated the survival (surviving specimens/total sampled specimens) and mortality (inhibited specimens/total sampled specimens) of P. pergandii for both larvae and females. In parallel, to evaluate the impact of the pesticide on natural enemies, we calculated the parasitism rate of $A$. hispanicus on females (parasitized females/total sampled females).

We checked for normality and homogeneity of variance for all variables via Kolmogorov-Smirnov test. To assess the mortality of larvae of P. pergandii, we used the independent $t$-test, considering the two stages as unrelated parameters [33]. The mortality among females (three stages) was tested by one-way ANOVA. We analyzed separately, for both larvae and females, the relationship between Spirotetramat inhibition effectiveness (mortalities of $P$. pergandii) and survival (surviving specimens of $P$. pergandii) by simple regression (linear model) [34], and all variables with $P$ values greater than 0.05 were considered non-significant.

To investigate the effectiveness of Spirotetramat, treatment doses as predictors of pest and parasitoid mortalities (response variables: with 0 (no mortalities) and 1 (at least one victim recorded)), a model with a binomial error structure and a logit link function was applied [35]. The model was applied for the totality of P. pergandii pests (all recorded specimens) and A. hispanicus parasitoids (all recorded parasitoids). In the case of parasitoids, the impact was reversed (the mortalities were considered as losses of natural enemies).

\section{Results}

\subsection{Impact on Larvae}

Among the 5115 recorded larvae (Figure 3), 79.73\% ( $n=4078)$ were inhibited, and only $20.27 \%(n=1037)$ survived after the treatment period. Equally, during stage 1 (larvae 1$)$, 
2441 larvae were dead and 841 survived. Similarly, during stage 2 (larvae 2), 1637 larvae were eliminated and 196 survived. Surviving larvae were more common during stage 1 (Table 1). Mortalities were higher during stage 1 . Mortalities and survival rates were uncorrelated during both stages (Figure 4).

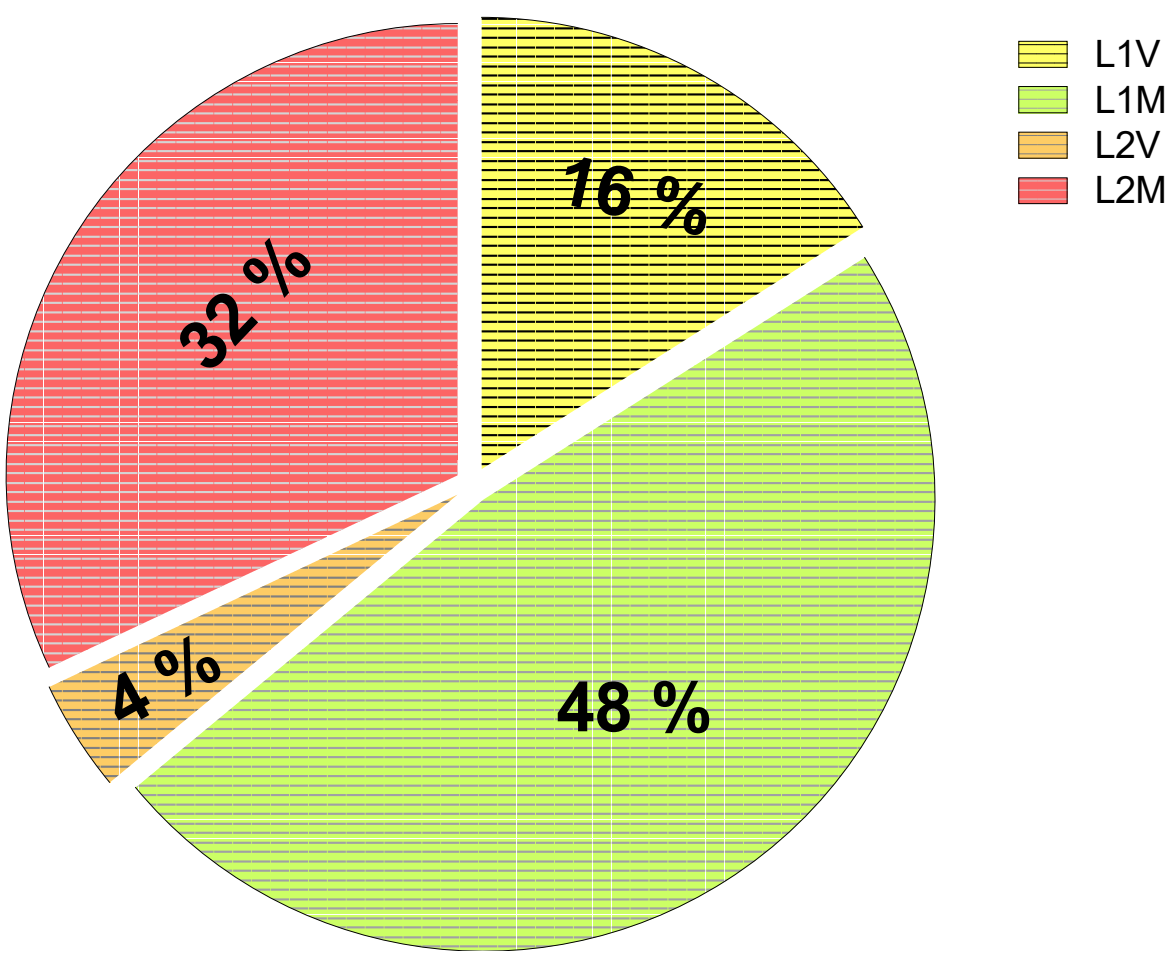

Figure 3. A comparison of mortalities (M) and survival rates (V) during two larvae stages (L1 and L2) of Parlatoria pergandii (L1V: surviving larvae of stage 1; L1M: dead larvae of stage 1; L2V: surviving larvae of stage 2; L2M: dead larvae of stage 2).
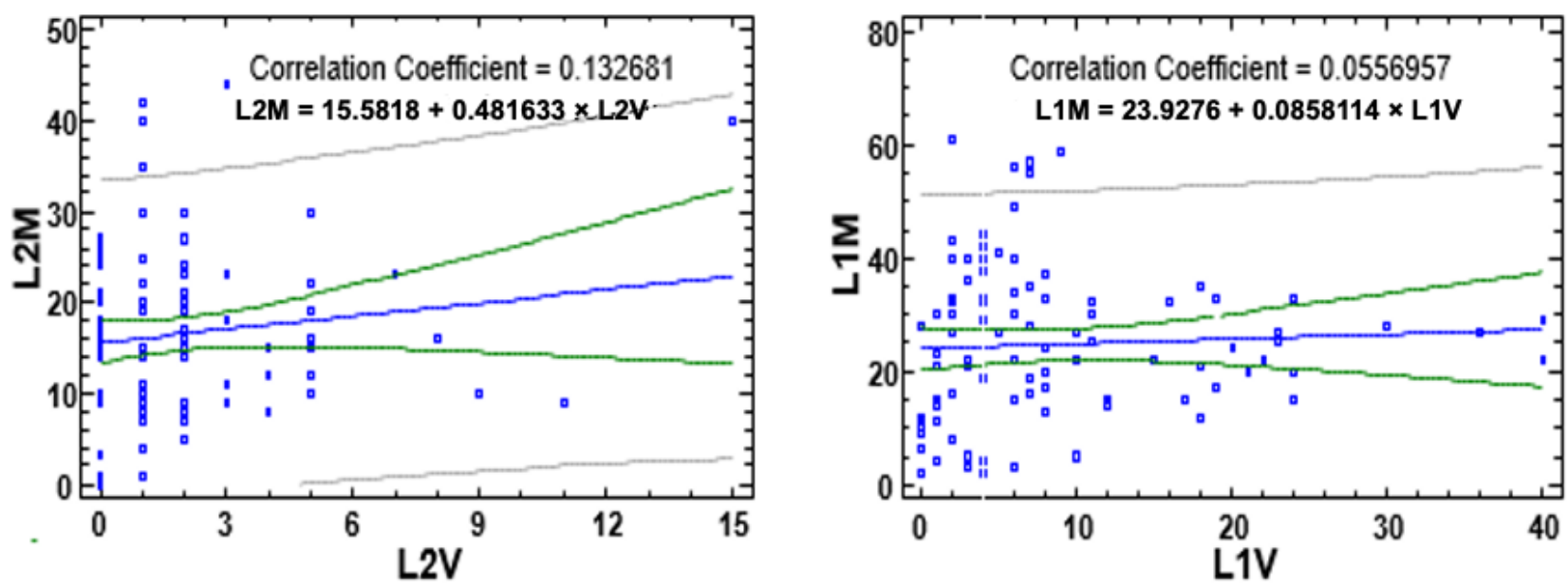

Figure 4. Analysis of the the survival rates of Parlatoria pergandii during stages larvae 1 and larvae 2.

In terms of the inhibition dose, the $\mathrm{T} 2$ of Spirotetramat was effective on larvae 1 with a mean of $29.37^{\mathrm{a}} \pm 2.94$, whereas the dose $\mathrm{T} 3$ was effective on larvae 2 with an average value of $21.48^{\mathrm{a}} \pm 1.82$ (Tables 2 and 3 ). On the contrary, the T1 was less effective at both larval stages. Moreover, the concentration of pesticide was correlated positively with the inhibition of larvae, and they were negatively correlated with insect survival. 
Table 1. A comparison of mortalities (M) and survival (V) rates among different larval stages of Parlatoria pergandii treated with Spirotetramat.

\begin{tabular}{cccc}
\hline Compared Parameters & $\boldsymbol{t}$ & df & $p$-Value \\
\hline L1V-L1M & -10.223 & 98 & 0.000 \\
L2V-L2M & -16.183 & 98 & 0.000 \\
L1V-L2V & 7.948 & 98 & 0.000 \\
L1M-L2M & 5.263 & 98 & 0.000 \\
\hline
\end{tabular}

Table 2. The survival (V) and mortality (M) of two larval stages (L1 and L2) of Parlatoria pergandii treated with different concentrations of Spirotetramat $(\mathrm{T} 0=0 \mathrm{~L} / \mathrm{ha}, \mathrm{T} 1=0.625 \mathrm{~L} / \mathrm{ha}, \mathrm{T} 2=0.755 \mathrm{~L} / \mathrm{ha}$, and $\mathrm{T} 3=1 \mathrm{~L} / \mathrm{ha})$.

\begin{tabular}{ccccc}
\hline & L1V & L1M & L2V & L2M \\
\hline T0 & $16.08^{\mathrm{a}} \pm 2.32$ & $17.70^{\mathrm{b}} \pm 1.73$ & $3.95^{\mathrm{a}} \pm 0.53$ & $11.75^{\mathrm{b}} \pm 1.19$ \\
\hline T1 & $5.04^{\mathrm{b}} \pm 0.68$ & $26.08^{\mathrm{a}} \pm 2.89$ & $0.91^{\mathrm{b}} \pm 0.17$ & $14.95^{\mathrm{ab}} \pm 1.19$ \\
\hline T2 & $6.12^{\mathrm{b}} \pm 1.46$ & $29.37^{\mathrm{a}} \pm 2.94$ & $0.79^{\mathrm{b}} \pm 0.15$ & $17.33^{\mathrm{a}} \pm 2.17$ \\
\hline T3 & $6.92^{\mathrm{b}} \pm 1.30$ & $25.37^{\mathrm{ab}} \pm 2.68$ & $2.22^{\mathrm{b}} \pm 0.61$ & $21.48^{\mathrm{a}} \pm 1.82$ \\
\hline
\end{tabular}

Values in the same column with different superscripts are significantly different $(p<0.05)$.

Table 3. Comparison of mortality (M), parasitism rates (P), and survival rates (V) of three female stages (F1, F2, and F3) of Parlatoria pergandii by one-way ANOVA during treatment dates.

\begin{tabular}{|c|c|c|c|c|c|c|}
\hline & & Sum of Squares & df & Mean Square & F & $p$-Value \\
\hline \multirow{3}{*}{ F1V } & Between Groups & 61.365 & 3 & 20.455 & 5.476 & 0.002 \\
\hline & Within Groups & 343.625 & 92 & 3.735 & & \\
\hline & Total & 404.990 & 95 & & & \\
\hline \multirow{3}{*}{$\mathrm{F} 2 \mathrm{~V}$} & Between Groups & 158.531 & 3 & 52.844 & 4.687 & 0.004 \\
\hline & Within Groups & 1037.208 & 92 & 11.274 & & \\
\hline & Total & 1195.740 & 95 & & & \\
\hline \multirow{3}{*}{ F3V } & Between Groups & 125.531 & 3 & 41.844 & 1.974 & 0.123 \\
\hline & Within Groups & 1950.208 & 92 & 21.198 & & \\
\hline & Total & 2075.740 & 95 & & & \\
\hline \multirow{3}{*}{ F1M } & Between Groups & 1766.365 & 3 & 588.788 & 8.181 & 0.000 \\
\hline & Within Groups & 6621.375 & 92 & 71.971 & & \\
\hline & Total & 8387.740 & 95 & & & \\
\hline \multirow{3}{*}{ F2M } & Between Groups & 3655.031 & 3 & 1218.344 & 6.511 & 0.000 \\
\hline & Within Groups & $17,213.958$ & 92 & 187.108 & & \\
\hline & Total & $20,868.990$ & 95 & & & \\
\hline \multirow{3}{*}{ F3M } & Between Groups & $11,303.865$ & 3 & 3767.955 & 13.589 & 0.000 \\
\hline & Within Groups & $25,509.292$ & 92 & 277.275 & & \\
\hline & Total & $36,813.156$ & 95 & & & \\
\hline \multirow{3}{*}{ F1P } & Between Groups & 618.698 & 3 & 206.233 & 19.971 & 0.000 \\
\hline & Within Groups & 950.042 & 92 & 10.327 & & \\
\hline & Total & 1568.740 & 95 & & & \\
\hline \multirow{3}{*}{$\mathrm{F} 2 \mathrm{P}$} & Between Groups & 78.781 & 3 & 26.260 & 0.382 & 0.767 \\
\hline & Within Groups & 6332.208 & 92 & 68.828 & & \\
\hline & Total & 6410.990 & 95 & & & \\
\hline \multirow{3}{*}{ F3P } & Between Groups & 279.750 & 3 & 93.250 & 0.516 & 0.672 \\
\hline & Within Groups & $16,634.750$ & 92 & 180.813 & & \\
\hline & Total & $16,914.500$ & 95 & & & \\
\hline
\end{tabular}

\subsection{Impact on Females}

Among the 14,657 recorded females (Figure 5), 26.04\% $(n=3816)$ were parasitized, $65.81 \%(n=9646)$ were inhibited, while only $8.15 \%(n=1195)$ were intact after the treatment period. In detail, during stage F1, only $1 \%(n=161)$ survived; $10 \%(n=1526)$ and $3 \%$ $(n=421)$ were inhibited and colonized by parasites, respectively. In addition, during 
stage F2, 3\% $(n=373)$ survived, $22 \%(n=3167)$ were eliminated, and 9\% $(n=1343)$ were parasitized. Equally, $4 \%(n=661)$ survived, $34 \%(n=4953)$ were inhibited, and $14 \%$ $(n=2052)$ were parasitized during stage F3.

In terms of a comparison among the stages, total surviving females and parasitism rates were higher during stage $3-4 \%$ and $14 \%$, respectively (Figure 5). Inhibited females were higher in number during stages two and three. On the other hand, survival rates were variable for all periods (Table 3). Similarly, eliminated females (F1M, F2M, and F3M) were different during monitoring dates. Parasitism rates were variable only during stage F1.

With respect to T0 (untreated plot), all three doses of the systemic product were effective on surviving females at stages two and three (F2V and F3V). The same effect was produced for dead females of stages 1 and 2 (F1M and F2M); however, for dead females of stage 3 (F3M), the concentration 0.755 (T2) was most effective, with an average of $57.25^{\mathrm{a}} \pm 5.07$. In addition, $\mathrm{T} 1$ ensured the higher parasitism rate at all three female stages (Tables 4 and 5). The average was $4.75^{\mathrm{ab}} \pm 0.93$ for females of stage $1,14.5^{\mathrm{b}} \pm 0.99$ for females of stage 2 , and $20.45^{\mathrm{b}} \pm 1.22$ for females of stage 3 .

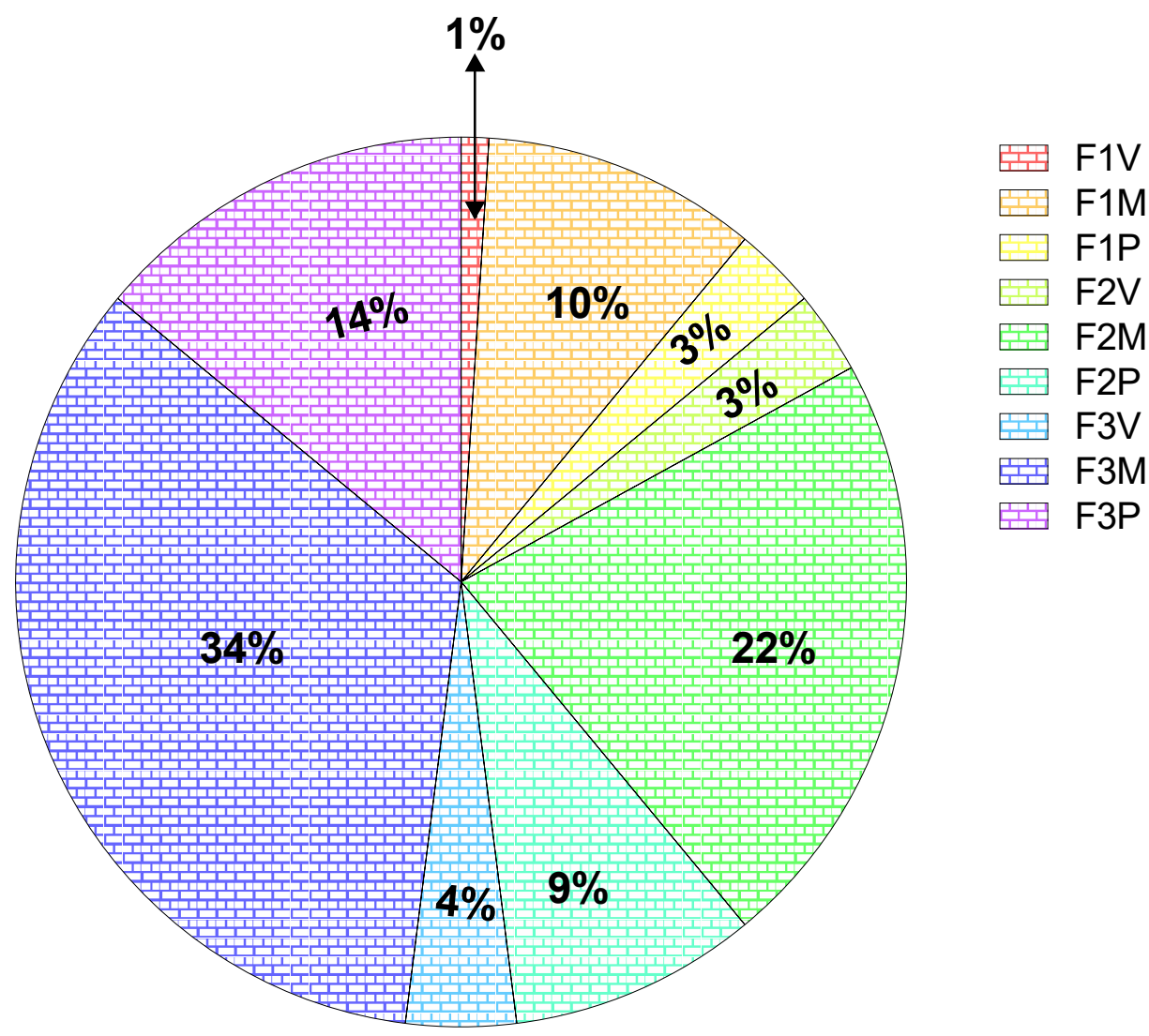

Figure 5. A comparison of mortalities $(M)$, parasitism rates $(P)$, and survival rates $(\mathrm{V})$ during three female stages (F1V: survived females of stage 1; F1M: dead females of stage 1; F1P: parasitized females of stage 1; F2V: surviving females of stage 2; F2M: dead females of stage 2; F2P: parasitized females of stage 2; F3V: surviving females of stage 3; F3M: dead females of stage 3; F3P: parasitized females of stage 3 ). 


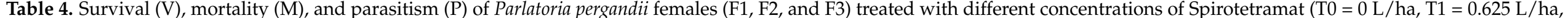
$\mathrm{T} 2=0.755 \mathrm{~L} / \mathrm{ha}$, and $\mathrm{T} 3=1 \mathrm{~L} / \mathrm{ha}$ ).

\begin{tabular}{|c|c|c|c|c|c|c|c|c|c|}
\hline & F1V & F1M & F1P & F2V & F2M & F2P & F3V & F3M & F3P \\
\hline T0 & $2.83^{a} \pm 0.41$ & $9.75^{b} \pm 0.94$ & $6.20^{a} \pm 0.79$ & $6.20^{a} \pm 0.92$ & $21.16^{b} \pm 2.27$ & $23.91^{\mathrm{a}} \pm 1.51$ & $12.08^{a} \pm 0.98$ & $42.41^{b} \pm 2.28$ & $40.25^{a} \pm 1.87$ \\
\hline $\mathrm{T} 1$ & $1.95^{\mathrm{ab}} \pm 0.59$ & $18.83^{\mathrm{a}} \pm 2.32$ & $4.75^{\mathrm{ab}} \pm 0.93$ & $3.66^{b} \pm 0.77$ & $37.16^{\mathrm{a}} \pm 2.21$ & $14.5^{b} \pm 0.99$ & $4.5^{b} \pm 0.50$ & $52.25^{\mathrm{ab}} \pm 3.20$ & $20.45^{b} \pm 1.22$ \\
\hline $\mathrm{T} 2$ & $1.16^{\mathrm{ab}} \pm 0.20$ & $18.16^{\mathrm{a}} \pm 1.82$ & $3.87^{a b} \pm 0.87$ & $2.58^{b} \pm 0.31$ & $40.20^{a} \pm 3.49$ & $8.79^{c} \pm 0.69$ & $4.58^{b} \pm 0.53$ & $57.25^{a} \pm 5.07$ & $13.45^{c} \pm 1.23$ \\
\hline T3 & $0.66^{b} \pm 0.15$ & $17.14^{\mathrm{a}} \pm 1.67$ & $2.90^{b} \pm 0.43$ & $2.47^{b} \pm 0.30$ & $32.95^{\mathrm{a}} \pm 2.23$ & $8.95^{c} \pm 1.02$ & $5.57^{b} \pm 0.59$ & $54.04^{\mathrm{ab}} \pm 4.41$ & $11.57^{c} \pm 1.11$ \\
\hline
\end{tabular}

Means that do not share a letter are significantly different. 
Table 5. Effect of treatment doses (T0: $0 \mathrm{~L} / \mathrm{Ha}$ Spirotetramat (as a witness experiment), $\mathrm{T} 1=0.625 \mathrm{~L} / \mathrm{Ha}, \mathrm{T} 2=0.755 \mathrm{~L} / \mathrm{Ha}$, and $\mathrm{T} 3=1 \mathrm{~L} / \mathrm{Ha}$ ) on the mortalities of Parlatoria pergandii, and the parasitoid Aphytis hispanicus.

\begin{tabular}{cccccc}
\hline & & Estimate & Standard Error & Wald Test & $p$-Value \\
\hline Survival & Intercept & -1.073 & 0.530 & 4.101 & 0.043 \\
& T0 & -0.118 & 0.038 & 9.523 & 0.002 \\
& T1 & 0.063 & 0.028 & 4.991 & 0.055 \\
& T2 & -0.001 & 0.002 & 0.525 & 0.539 \\
& T3 & -0.136 & 0.563 & 0.561 & 0.056 \\
& Scale & 1.000 & 0.000 & & \\
\hline Mortalities & Intercept & -1.046 & 0.480 & 5.212 & 0.065 \\
& T0 & -0.161 & 0.073 & 8.431 & 0.042 \\
& T1 & 0.058 & 0.033 & 9.047 & 0.002 \\
& T2 & -0.051 & 0.012 & 10.321 & 0.001 \\
& T3 & -0.456 & 0.451 & 0.621 & $<0.001$ \\
& Scale & 1.000 & 0.000 & & \\
\hline Parasitoid & Intercept & -1.064 & 0.690 & 5.654 & 0.007 \\
Survival & T0 & -0.543 & 0.053 & 10.632 & 0.001 \\
& T1 & 0.454 & 0.032 & 7.431 & 0.05 \\
& T2 & -0.034 & 0.0453 & 0.565 & 0.789 \\
& T3 & -0.136 & 0.563 & 0.674 & 0.796 \\
& Scale & 1.000 & 0.000 & & \\
\hline
\end{tabular}

\section{Discussion and Conclusions}

To our knowledge, this is the first study on the use of chemical treatment to control P. pergandii. Our main aim was to provide detailed data on the effectiveness of Spirotetramat regarding the pest and the secondary effect on the parasitoid $A$. hispanicus. These findings provided the first set of data related to the control of $P$. pergandii in citrus in Morocco and the entire Northwest African zone, which should be of great interest for the undertaking of new comparative studies and the adoption of sustainable doses to control the pest and protect the natural enemies.

Our results showed that in the larval stage the inhibition was nearly $80 \%$, whereas in the adult stage the inhibition rate was lower. These results are similar to the results reported for other pests, including the citriculus mealybug Pseudococcus cryptus (Hempel), the spherical mealybug Nipaecoccus viridis (Newstead), the longtailed mealybug P. longispinus (Targioni-Tozzetti), Planococcus citri (Risso), the citrophilus mealybug P. calceolariae (Maskell), and the obscure mealybug P. viburni (Signoret) treated by different control methods and substances in the same area [36,37]. The lower mortality rates in females are mainly due to the vulnerability of larval stage [38]. Equally, females are characterized by their resistance toward chemicals, and this is considered among the issues of pesticide use in pest control [38,39].

In larval stages, the effectiveness of the concentrations was variable. T2 $(0.755 \mathrm{~L} / \mathrm{Ha})$ was effective against larvae 1 , and T3 $(0.625 \mathrm{~L} / \mathrm{Ha})$ was effective on larvae 2 . Increasing the amount of pesticide applied significantly increased the inhibition rate observed. However, the main goal was using the minimum pesticide concentration necessary to achieve effective control of $P$. pergandii. This approach will allow lower pesticide use and avoid the development of pesticide resistance. Consequently, less residues should remain on the fruits and in the soil $[40,41]$.

Among the 14,657 recorded females, 26.04\% were parasitized, 65.81\% were inhibited, and only $8.15 \%$ were intact after the treatment period. In Algeria, similar results were mentioned for citrus: Spirotetramat controlled P. pergandii with encouraging results [42]. However, the effectiveness each concentration was variable depending on the insect stage. In fact, all three concentrations of the systemic product were effective on surviving females of stages two and three (F2V and F3V); the same was true for dead females of stages 1 and 2 (F1M and F2M); however, for dead females of stage 3 (F3M), the low concentration 
0.625 (T1) was most effective. T1 ensured the highest parasitism rate for all three female stages. Therefore, $0.625 \mathrm{~L} / \mathrm{Ha}$ is suggested to be less harmful to the environment and natural enemies. In Algeria, the same results were reported by [43]: all the doses used of Spirotetramat were effective on the population of $P$. blanchardi on date palms. Therefore, the choice of the right concentration remains a necessity in order to preserve the agroecosystem [44]. Generally, high quantities of pesticides allow one to control pests, but they negatively influence natural enemies of pests and the environment. On the other hand, the combination of natural enemies and low pesticide doses would allow effective and eco-friendly control of P. pergandii.

Our findings highlight four key messages: (1) data indicate that Spirotetramat was most effective on the larvae of P. pergandii; (2) the lowest dose was effective on different stages of female and had a low impact on the parasitoid A. hispanicus; (3) the combination of chemical measures and natural enemies will reduce the population of P. pergandii on citrus trees in the Gharb plain; (4) the use of small doses of the pesticide will reduce the impact on the environment and reduce the resistance of the insect. Given that Spirotetramat is an effective pesticide and is widely used, more studies on its effects on other populations of natural enemies and the residues remaining on fruits are needed to establish proper management strategies.

Author Contributions: Conceptualization, A.A. and A.L.; methodology, A.A. and I.M.; validation, W.S. and M.K.; data curation, H.M., H.I., R.C. and M.N.A.; writing-original draft preparation, A.A.; writing-review and editing, R.C. and M.N.A.; supervision, A.L. and A.F. All authors have read and agreed to the published version of the manuscript.

Funding: This research was funded by the Deanship of Scientific Research at Princess Nourah bint Abdulrahman University through the Fast-track Research Funding Program.

Data Availability Statement: The data presented in this study are available on request from the corresponding author.

Acknowledgments: The authors are thankful to the Deanship of Scientific Research at Princess Nourah bint Abdulrahman University for the support of this research through the Fast-track Research Funding Program.

Conflicts of Interest: The authors declare no conflict of interest.

\section{References}

1. Dambier, D.; Benyahia, H.; Pensabene-Bellavia, G.; Kaçar, Y.A.; Froelicher, Y.; Belfalah, Z.; Lhou, B.; Handaji, N.; Printz, B.; Morillon, R. Somatic Hybridization for Citrus Rootstock Breeding: An Effective Tool to Solve Some Important Issues of the Mediterranean Citrus Industry. Plant Cell Rep. 2011, 30, 883-900. [CrossRef] [PubMed]

2. Klein, J.D. Citron cultivation, production and uses in the Mediterranean region. In Medicinal and Aromatic Plants of the Middle-East; Springer: Berlin/Heidelberg, Germany, 2014; pp. 199-214.

3. El-Otmani, M.; Coggins, C.W.; Duymovic, A. Citrus Cultivars and Production in Morocco. HortScience 1990, 25, 1343-1346. [CrossRef]

4. Oubelkacem, A.; Scardigno, A.; Choukr-Allah, R. Treated Wastewater Reuse on Citrus in Morocco: Assessing the Economic Feasibility of Irrigation and Nutrient Management Strategies. Integr. Environ. Assess. Manag. 2020, 16, 898-909. [CrossRef]

5. Porat, R.; Weiss, B.; Cohen, L.; Daus, A.; Aharoni, N. Reduction of Postharvest Rind Disorders in Citrus Fruit by Modified Atmosphere Packaging. Postharvest Biol. Technol. 2004, 33, 35-43. [CrossRef]

6. Prusky, D. Reduction of the Incidence of Postharvest Quality Losses, and Future Prospects. Food Secur. 2011, 3, 463-474. [CrossRef]

7. Tena, A.; Garcia-Marí, F. Current Situation of Citrus Pests and Diseases in the Mediterranean Basin. IOBC Bull. 2011, 62, 365-368.

8. Gutierrez, A.P.; Ponti, L. Prospective Analysis of the Geographic Distribution and Relative Abundance of Asian Citrus Psyllid (Hemiptera: Liviidae) and Citrus Greening Disease in North America and the Mediterranean Basin. Fla. Entomol. 2013, 96, 1375-1391. [CrossRef]

9. Ali, N. Communautés de Nématodes Phytoparasites Associés à L'olivier: Réponse Aux Forçages Anthropiques et Environnementaux. Ph.D. Thesis, Montpellier SupAgro, Montpellier, France, 2015.

10. Mazih, A. Current Situation of Citrus Pests and the Control Methods in Use in Morocco. IOBC WPRS Bull. 2008, 38, 10-16.

11. Mazih, A. Status of Citrus IPM in the Southern Mediterranean Basin Morocco, North Africa. Acta Hortic. 2015, 1065, 1097-1103. [CrossRef] 
12. Elekcioğlu, N.Z.; Ölçülü, M. Determination of Parasitoid and Predator Species of Chaff Scale [Parlatoria Pergandii Comstock (Hemiptera: Diaspididae)] in Citrus Orchards in Eastern Mediterranean Region of Turkey. Bitki Koruma Bülteni 2018, 58, 131-139.

13. Jendoubi, H.; Suma, P.; Russo, A. Response of the Parlatoria Citrus Scale Insects (Hemiptera, Coccoidea) to Coloured Sticky Traps. In Proceedings of the VII International Scientific Agriculture Symposium, "Agrosym 2016", Jahorina, Bosnia and Herzegovina, 6-9 October 2016; pp. 1529-1535.

14. Jaouad, M.; Moinina, A.; Ezrari, S.; Lahlali, R. Key Pests and Diseases of Citrus Trees with Emphasis on Root Rot Diseases: An Overview. Moroc. J. Agric. Sci. 2020, 1, 149-160.

15. Arenstein, Z.; Ausher, R.; Beicht, W.; Blair, B.D.; Blazquez, C.H.; Dinoor, A.; Dishon, I.; Edelbaum, G.; Elkana, J.; Eshel, J. Advisory Work in Crop Pest and Disease Management; Springer Science \& Business Media: Berlin/Heidelberg, Germany, 2012.

16. Michael, G.; Ong'amo, G.O.; Nderitu, J.; Watson, G.W.; Kinuthia, W. Diversity of Scale Insects (Hemiptera: Coccomorpha) Attacking Citrus Trees in Machakos, Makueni, Kilifi and Kwale Counties, Kenya. J. Agric. Sci. Pract. 2021, 6, 79-85.

17. Damalas, C.A.; Eleftherohorinos, I.G. Pesticide Exposure, Safety Issues, and Risk Assessment Indicators. Int. J. Environ. Res. Public Health 2011, 8, 1402-1419. [CrossRef] [PubMed]

18. Weng, C.-Y.; Black, C. Taiwanese Farm Workers' Pesticide Knowledge, Attitudes, Behaviors and Clothing Practices. Int. J. Environ. Health Res. 2015, 25, 685-696. [CrossRef] [PubMed]

19. Soto, A.; Costa-Comelles, J.; Alonso, A.; Rodriguez, J.M. Efficacy of Some Citrus Pesticides on the Diaspidid Scales Lepidosaphes Beckii (Newman) and Parlatoria Pergandii Comstock (Homoptera, Diaspididae) and Impact on Nontarget Organisms. Bol. Sanid. Veg. Plagas Esp. 1994, 20, 357-369.

20. Berni, I.; Menouni, A.; El, I.G.; Duca, R.-C.; Kestemont, M.-P.; Godderis, L.; El, S.J. Understanding Farmers' Safety Behavior Regarding Pesticide Use in Morocco. Sustain. Prod. Consum. 2021, 25, 471-483. [CrossRef]

21. El Bakouri, H.; Aassiri, A.; Morillo, J.; Usero, J.; Khaddor, M.; Ouassini, A. Pesticides and Lipids Occurrence in Tangier Agricultural Soil (Northern Morocco). Appl. Geochem. 2008, 23, 3487-3497. [CrossRef]

22. Abbassi, M. Notes Bio-Écologiques Sur Parlatoria Pergandei COMSTOCK (Homopt. Coccidae) Au Maroc. Fruits 1975, 30, 179-184.

23. García-Marí, F.; Rodrigo, E. Life Cycle of the Diaspidids Aonidiella Aurantii, Lepidosaphes Beckii and Parlatoria Pergandii in an Orange Grove in Valencia (Spain). IOBC WPRS Bull. 1995, 18, 118.

24. Jebbour, Y.; Abbassi, M. Recrudescence Du Pou Violet Parlatoria Pergandii (Comstock). Homoptera Diaspi-Didae, Sur Agrumes Au Maroc: Biologie et Écologie de l'espèce. Al Awamia 2006, 3, 118-119.

25. Rodrigo, M.E.; Garcia-Mari, F.; Rodriguez-Reina, J.M.; Olmeda, T. Colonization of Growing Fruit by the Armored Scales Lepidosaphes Beckii, Parlatoria Pergandii and Aonidiella Aurantii (Hom., Diaspididae). J. Appl. Entomol. 2004, 128, 569-575. [CrossRef]

26. Rosen, D.; De Bach, P. Species of Aphytis of the World (Hymenoptera: Aphelinidae); Series Entomologica; Junk, W., Ed.; The Hague: Boston, MA, USA; London, UK, 1979; Volume 17.

27. Rodrigo, E.; Troncho, P.; García-Marí, F. Parasitoeds (Hym.: Aphelinidae) of Three Scale Insects (Hom.: Diaspididae) in a Citrus Grove in Valencia, Spain. Entomophaga 1996, 41, 77-94. [CrossRef]

28. Planes, L.; Catalán, J.; Tena, A.; Porcuna, J.L.; Jacas, J.A.; Izquierdo, J.; Urbaneja, A. Lethal and Sublethal Effects of Spirotetramat on the Mealybug Destroyer, Cryptolaemus Montrouzieri. J. Pest Sci. 2013, 86, 321-327. [CrossRef]

29. Kühnhold, J.; Klueken, A.M.; De Maeyer, L.; Van Waetermeulen, X.; Brück, E.; Elbert, A. Movento ${ }^{\circledR}$, an Innovative Solution for Sucking Insect Pest Control in Agriculture: Field Performance in Fruits and Vegetables. Bayer Crop. J. 2008, 61, $279-306$.

30. Mohapatra, S.; Deepa, M.; Jagadish, G.K. An Efficient Analytical Method for Analysis of Spirotetramat and Its Metabolite Spirotetramat-Enol by HPLC. Bull. Environ. Contam. Toxicol. 2012, 88, 124-128. [CrossRef] [PubMed]

31. Hassouni, T.; Belghyti, D. Distribution of Gastrointestinal Helminths in Chicken Farms in the Gharb Region-Morocco. Parasitol. Res. 2006, 99, 181-183. [CrossRef]

32. Benyahia, H.; Talha, A.; Fadli, A.; Chetto, O.; Omari, F.E.; Beniken, L. Performance of 'Valencia Late'Sweet Orange (Citrus Sinensis) on Different Rootstocks in the Gharb Region (Northwestern Morocco). Annu. Res. Rev. Biol. 2017, 20, 1-11. [CrossRef]

33. Mansouri, I.; Squalli, W.; El Agy, A.; El-Hassani, A.; El Ghadraoui, L.; Dakki, M. Comparison of Nesting Features and Breeding Success of Turtle Dove Streptopelia Turtur between Orchards and Riparian Habitats. Int. J. Zool. 2021, 2021, 5566398. [CrossRef]

34. Cankaya, S. A Comparative Study of Some Estimation Methods for Parameters and Effects of Outliers in Simple Regression Model for Research on Small Ruminants. Trop. Anim. Health Prod. 2009, 41, 35-41. [CrossRef]

35. Abdel-Aty, M.; Abdalla, M.F. Modeling Drivers' Diversion from Normal Routes under ATIS Using Generalized Estimating Equations and Binomial Probit Link Function. Transportation 2004, 31, 327-348. [CrossRef]

36. Berlinger, M.J.; Gol'berg, A.M. The Effect of the Fruit Sepals on the Citrus Mealybug Population and on Its Parasite. Entomol. Exp. Appl. 1978, 24, 238-243. [CrossRef]

37. Franco, J.C.; Suma, P.; Da Silva, E.B.; Blumberg, D.; Mendel, Z. Management Strategies of Mealybug Pests of Citrus in Mediterranean Countries. Phytoparasitica 2004, 32, 507-522. [CrossRef]

38. Carrière, Y. Haplodiploidy, Sex, and the Evolution of Pesticide Resistance. J. Econ. Entomol. 2003, 96, 1626-1640. [CrossRef]

39. Kedia, A.; Prakash, B.; Mishra, P.K.; Singh, P.; Dubey, N.K. Botanicals as Eco Friendly Biorational Alternatives of Synthetic Pesticides against Callosobruchus Spp. (Coleoptera: Bruchidae)-A Review. J. Food Sci. Technol. 2015, 52, 1239-1257. [CrossRef] 
40. Amirahmadi, M.; Shoeibi, S.; Abdollahi, M.; Rastegar, H.; Khosrokhavar, R.; Hamedani, M.P. Monitoring of Some Pesticides Residue in Consumed Tea in Tehran Market. Iran. J. Environ. Health Sci. Eng. 2013, 10, 1-6. [CrossRef]

41. Bajwa, U.; Sandhu, K.S. Effect of Handling and Processing on Pesticide Residues in Food-A Review. J. Food Sci. Technol. 2014, 51, 201-220. [CrossRef] [PubMed]

42. Urbaneja, A.; Grout, T.G.; Gravena, S.; Wu, F.; Cen, Y.; Stansly, P.A. Citrus pests in a global world. In The Genus Citrus; Elsevier: Amsterdam, The Netherlands, 2020; pp. 333-348.

43. Belkhiri, D.; Biche, M.; Mehaoua, M.S. Effet de Spirotetram Ate Surl' Evolution des Larves et des Adultes de Parlatoria Blanchardi du Palmier Dattier en Algerie Parlatoria Blanchardi of the Date Palm in Algeria. Courr. Savoir 2018, 25, $157-161$.

44. Stanley, J.; Preetha, G. Pesticide Toxicity to Non-Target Organisms: Exposure, Toxicity and Risk Assessment Methodologies; Springer: Berlin/Heidelberg, Germany, 2016; ISBN 978-94-017-7752-0. 